\title{
Lunar and planetary periodicity of failure years in Finland and in Sweden
}

\author{
Tauno Mannila \\ Myllytie 3 A 7, 00140 Helsinki 14
}

\begin{abstract}
Of the 47 failure years in Finland between 1347-1929 $40 \%$ have occurred in years that correspond to the lunar period 4.9035 years. The result of a study of 77 failure years in Sweden during 1526-1772 was similar. When the positions of planets in a failure year have been repeated or the angular distances of the four giant planets have been isogonal the failure might also have been repeated. - The amount of spring wheat crop per hectare in Finland during the years 1920-1979 has been reduced in relation to the foregoing and/or the following year in years corresponding to the lunar periodicity of 4.9035 years as this scale LR-agr. has been started from a growth season during which the amount of rain has been below average. - Still greater reduction of crop and frequency of $9 / 10$ years has occurred in Finland in the years corresponding to the planetary scale P32agr., which covers the period of 5.5613 years. Scale P32agr. represents a growth season in which the temperature was below average during $61 \%$ of the time and the amount of rain in May and in July was below average but in August exceeded the average. A meteorological scale P32 completes scale P32agr. With the scales predictions of years could be made in which reduction of crop can be expected.
\end{abstract}

\section{Introduction}

The numerous factors affecting the climate and the periodicity of changes have been clearly recorded by LAMB (1972). About the periods he writes as follows: "Cyclic tendencies around 30 days, $13-14$ months, $2-3$ years, $51 / 2$, $11,19,22-23,90,100,200$ and 400 years (as well as some much longer cycles) may be accepted as playing an important part in the variations we observe - though most are only quasi-periodicities of somewhat variable period and amplitude." These figures are indications of the many studies in which one has tried to find regularity in changes of the climate with the aid of mere statistics.

Among other studies should be mentioned the one that tries to deduce the later development of the weather during the period of growth from the spring weather based on earlier similar situations (CH ICHASOv 1973); a comparison of the weather of the same month during several years (WRIGHT and FLOOD 1973) and an analysis of statistics of the length of rainy periods (FEKETE and SZEPESI 1974). 
The leading idea of the following study is to find out the possible influence of the lunar and planetary mechanics through gravitation changes on weather variations and further due to them on variations in the amounts of crops.

\section{Material and methods}

The object of this study was first of all the 47 failure years during the years 1347-1929 in Finland (Grotenfelt 1919, 1934) and the 77 failure years during 1526-1772 in Sweden (ЕKMAN 1783).

The data of the areas of cultivation and the amounts of the yearly crop in Finland during the time $1920-1979$ are obtained from the statistics of the National Board of Agriculture in Finland.

As a lunar period the time of 65 anomalous months i.e. 4.903530 years has been used and as a planetary period the time of 5.561343 years, which period is $1 / 32$ of the planetary subperiod of 177.96298 years (MANNILA 1980).

The lunar scale has been used first of all in the study of the appearance of failure years. In the second phase the start of the lunar LR-agr. has been a growth season during which the amount of rain has been below average.

The start of the planetary scale P32agr. is a growth season in which the temperature has been below average. However, another so-called meteorological planetary period P32 has also been used, the start of which is 0.997 years later than that of P32agr. The yearly temperatures in the years of the scale P32 are below average.

In the determination of the heliocentric position of the planets a hundredth part of a circle (abbreviated cc) has been used as the angle unit.

\section{Results}

\section{Failure of crops}

\section{Lunar periodicity}

When 47 failure years from the period 1347-1929 in Finland are placed in a scale of four lunar periods $(A-D)$, i.e. 19.61 years, we get a result according to Figure 1: $19 / 47$ of the bad years occur in groups at intervals of 4.9035 years. The same result is shown in Figure 2, in which the above mentioned four

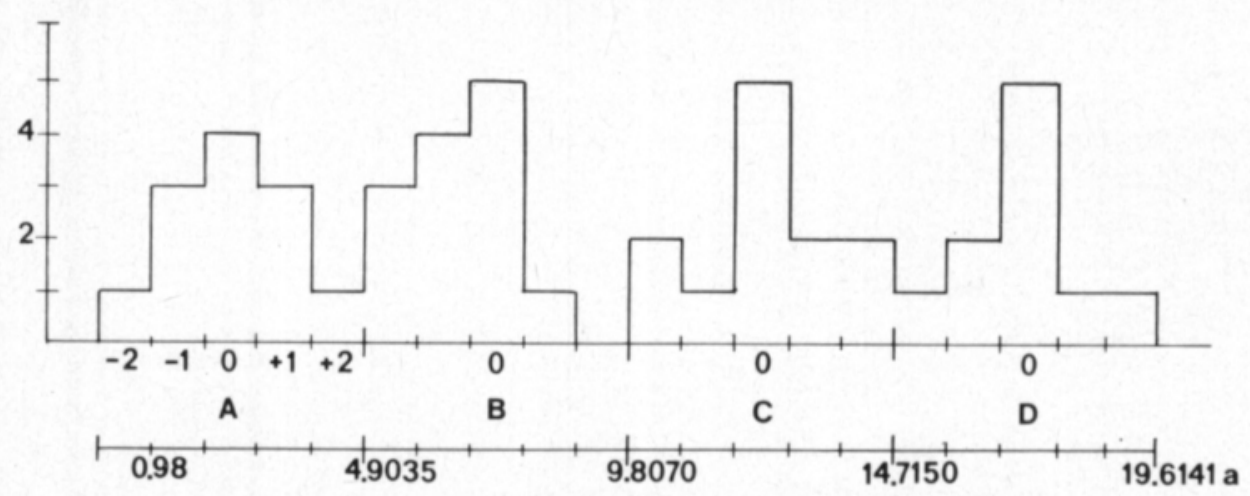

Fig. 1. 47 failure years during 1347-1929 in Finland are placed in a scale of four lunar periods $(A-D)$, i.e. 19.61 years. $40 \%$ of the bad years occur in groups in intervals of 4.9035 years. 

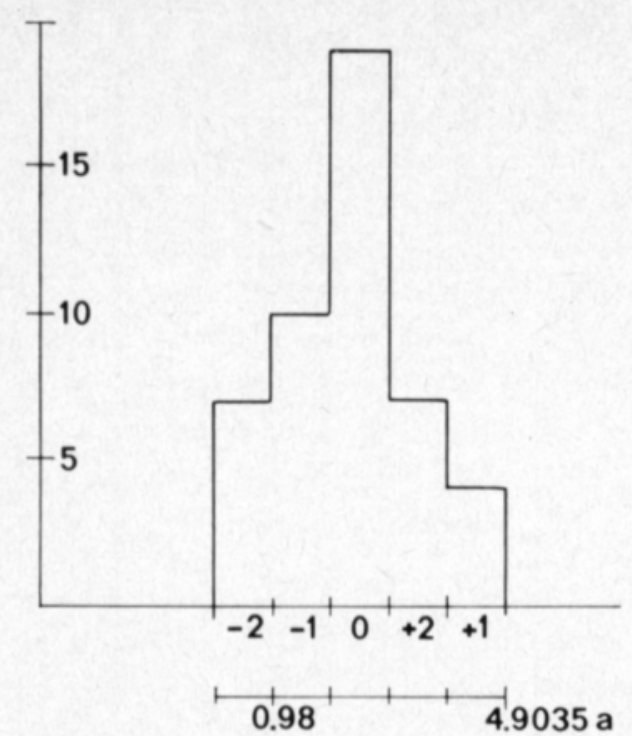

Fig. 2. The four lunar periods $A-D$ (Fig. 1) have been combined.

Table 1. The failure years in Finland during 1347-1929. 47 bad years in a scale of four 4.90353 years period (A, B, C and D) i.e. 19.61 years. Start: 1866.63. - years before the scale time, + years after the scale time, 0 at the scale time.

\begin{tabular}{|c|c|c|c|c|c|}
\hline $\begin{array}{c}\text { Failure } \\
\text { year }\end{array}$ & Scale & Group & $\begin{array}{c}\text { Failure } \\
\text { year }\end{array}$ & Scale & Group \\
\hline 1347 & 1346.85582 & D & 1726 & 1724.42763 & $A+1$ \\
\hline 1352 & 1351.75937 & A & 1740 & 1739.13822 & D 0 \\
\hline 1391 & 1390.28761 & A & 1941 & & $D+1$ \\
\hline 1421 & 1420.40877 & $\mathrm{C}$ & 1756 & 1753.84881 & $C+2$ \\
\hline 1445 & 1444.92642 & D $\quad 0$ & 1763 & 1763.65587 & $A-1$ \\
\hline 1527 & 1528.28643 & $A-2$ & 1769 & 1768.5594 & B 0 \\
\hline 1528 & & $A-1$ & 1776 & 1773.46293 & $C+2$ \\
\hline 1542 & 1542.99702 & $D-1$ & 1783 & 1783.26999 & $A-1$ \\
\hline 1543 & & D $\quad 0$ & 1784 & & A 0 \\
\hline 1600 & 1601.83938 & $\mathrm{D}-2$ & 1785 & & $A+1$ \\
\hline 1601 & & $\mathrm{D}-1$ & 1833 & 1832.30529 & C $\quad 0$ \\
\hline 1602 & & D 0 & 1862 & 1861.72647 & A 0 \\
\hline 1631 & 1631.26056 & $B-1$ & 1865 & 1866.63000 & B -2 \\
\hline 1632 & & B 0 & 1866 & & B -1 \\
\hline 1633 & & $B+1$ & 1867 & & B 0 \\
\hline 1635 & 1636.16409 & $C-2$ & 1892 & 1891.72647 & C $\quad 0$ \\
\hline 1649 & 1650.87468 & $B-2$ & 1893 & & $c+1$ \\
\hline 1650 & & $B-1$ & 1902 & 1900.95471 & $A+1$ \\
\hline 1656 & 1655.77821 & C 0 & 1918 & 1915.0653 & $D+2$ \\
\hline 1695 & 1695.00645 & $C-1$ & 1923 & 1920.56883 & $A+2$ \\
\hline 1696 & & C $\quad 0$ & 1926 & 1925.47236 & B 0 \\
\hline 1697 & & $c+1$ & 1929 & 1930.37589 & $c-2$ \\
\hline 1708 & 1709.71704 & B -2 & & & \\
\hline 1709 & & $B-1$ & & & \\
\hline 1710 & & B 0 & & & \\
\hline
\end{tabular}

Summary: \begin{tabular}{rrrrr}
$\frac{-2}{2}$ & -1 & 0 & +1 & +2 \\
\hline 7 & 10 & 19 & 7 & 4
\end{tabular} 
periods $\mathrm{A}, \mathrm{B}, \mathrm{C}$ and $\mathrm{D}$ have been combined. - The division of the failure years into the scale of 4.9035 year periods is presented in Table 1 .

The result was similar when a corresponding investigation was made into 77 failure years from the period 1526-1772 in Sweden, shown in Figure 3.

In this material, however, there are many "weak years". In this case the failure was obviously caused by other than meteorological factors such as the lack of seed corn, the weakness of technical methods, and illnesses in the population, such as pestilence and other contagious diseases. For these reasons probably the base of the diagram in Figure 3 is higher than in Figure 2.

\section{Planetary periodicity}

The relation of the failure of crop to the planetary periodicity is shown in Figure 4. In this figure are presented the mutual heliocentric positions of the four giant planets, Jupiter, Saturn, Uranus and Neptune at the twelve years of failure times in Finland. It can be ascertained that when the angular distances between the planets are repeated, in these cases also the failure is repeated, even if the positions of the planets are the same or there is a mirror image of the positions in question.

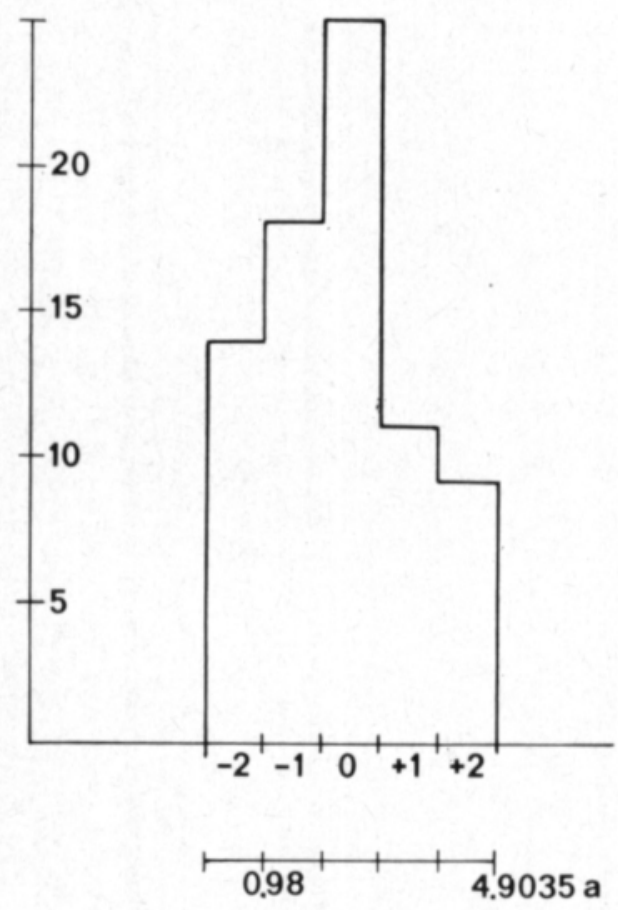

Fig. 3. 77 failure years during $1526-1780$ in Sweden are placed in a scale of one lunar period, i.e. 4.9035 years.

\section{The crops of the spring wheat}

The relations of the crops of spring wheat in Finland to a lunar period and to two planetary periods can be seen in Figure 5 . 
4

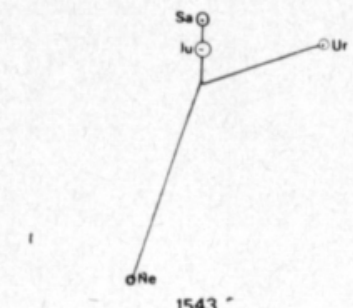

$1543^{\circ}$

1862

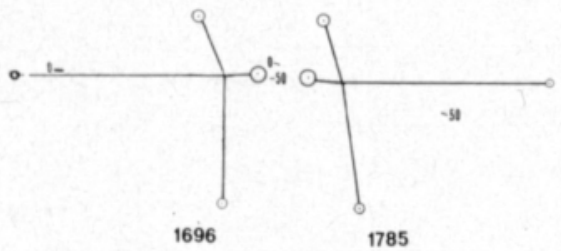

s

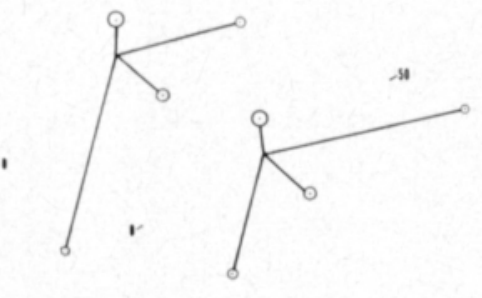

1709

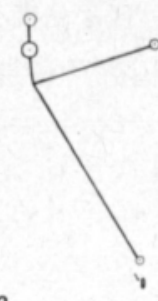

1785

1769

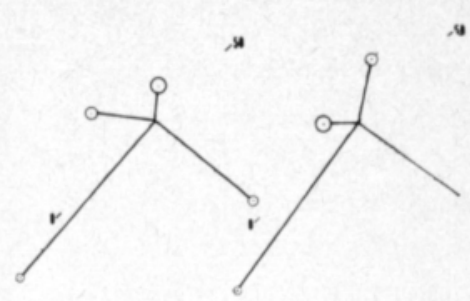

1697

\$
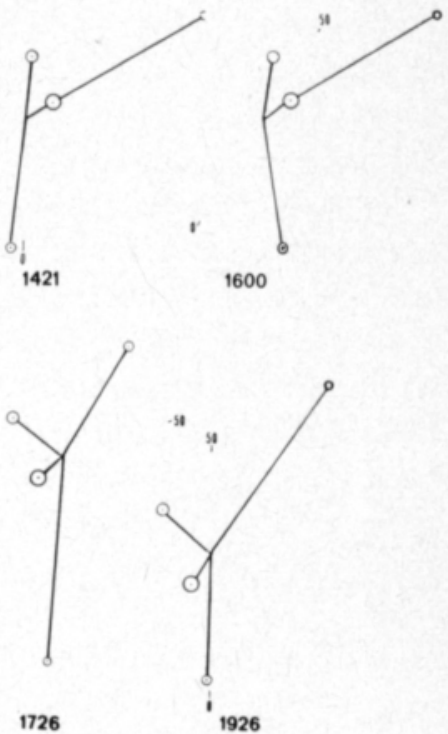

Fig. 4. The mutual heliocentric positions of the giant planets Jupiter (Ju), Saturn (Sa), Uranus (Ur) and Neptune (Ne) at the times of twelve years of failure in Finland.

321. Lunar periodicity

As a lunar period there is the meteorological scale LR - (MANnILA 1980), which represents a poor amount of rain, less than average in a year. However, the start of the scale is 0.23 year earlier than the start of the meteorological scale, and the name of the scale is therefore LR-agr.

From Table 2 it can be seen that the amounts of rain in Helsinki in the year of the scale LR-agr. have been below average in May and July in eight years out of twelve, and also that the amount of rain in all four months of the season has been below average in 60 per cent of the time.

It can be ascertained from Figure 5 that in the years of the lunar scale LRagr. the amount of crop of spring wheat in kilogrammes per hectare in Finland has been reduced to some degree in relation to the amount of crop in the foregoing and/or the following year. This reduction can be clearly seen e.g. from the amount of crop in the years 1941, 1946, 1951, 1956 and in 1975.

322. Planetary periodicity

The planetary scale P32agr., in which the periods are 5.5613 years, is placed in Figure 5 below the diagram so that the start of the scale is in the 
mathematical time 1961.2578, which corresponds to the crop failure in the year 1962. It can be seen that in the years of this period the harvest per hectare has been less than in the foregoing years in 9 out of 10 years.

The relation of the monthly temperature of the growth season to the monthly temperature average can be ascertained from Table 3 . In the years of the scale during 1923-1978 the temperature in May and June was below average in 6 out of 11 years, in July in 7 and in August in 8 out of 11 years.

The relative amount of rain in the years of the same scale is shown in Table 4. From May to the end of August the amount of rainy days has been variable. However, the amount of rain in the groups of Mays and Julys has been below average in 7 out of 11 years, while in the group of Augusts it has been above average in the same ratio, even over $100 \mathrm{~mm}$ in 5 out of 11 years.

The meteorological scale P32 as well completes the scale P 32 agr. This meteorological scale P32, the start of which is the mathematical time 1856 . 5895 (MannILA 1980), represents years in which the temperature is below average especially in summertime, and particularly August, September and October are rich in rain.

The amount of crop per hectare in the years of the scale P32 has been less than the amount in the foregoing year in a ratio of 5 to 10 , and in the years of the last $5 / 10$ the amount of crop has often been rather poor. This meteorological scale P32 may be found also under the diagram in Figure $\mathbf{5}$.

Table 2. Lunar Scale LR-agr. Amount of rain in the growth season compared with average. Helsinki 1921-1975. Period: 4.903530 y. Start: 1920.773835 . - below average, +- average, + above average, $++>70 \mathrm{~mm},+++>100 \mathrm{~mm}$.

\begin{tabular}{|c|c|c|c|c|c|c|c|c|}
\hline $\begin{array}{l}1931-1960 \\
\text { average, } \mathrm{mm} .:\end{array}$ & & 42 & 37 & 47 & 62 & 66 & 66 & 647 \\
\hline Scale & Year & (Apr.) & May & June & July & Aug. & (Sept.) & Year \\
\hline 1920.7738 & 1921 & - & - & + & - & - & - & 705.8 \\
\hline 1925.6773 & 1926 & - & ++ & - & - & + & - & 563.2 \\
\hline 1930.5808 & 1931 & - & + & + & - & - & ++ & 701.5 \\
\hline 1935.4844 & 1936 & - & ++ & - & + & - & - & 640.5 \\
\hline 1940.3879 & 1941 & - & - & - & - & +++ & - & 496 \\
\hline 1945.2914 & 1946 & - & + & + & - & - & ++ & 578 \\
\hline 1950.1950 & 1951 & + & - & + & - & - & - & 556 \\
\hline 1955.0985 & 1956 & + & - & - & $++t$ & $++t$ & - & 711 \\
\hline 1960.0020 & 1961 & - & - & + & + & ++ & - & 580 \\
\hline 1964.9056 & 1965 & - & - & + & - & ++ & ++ & 605 \\
\hline 1969.8091 & 1970 & ++ & - & - & $++t$ & - & ++ & 711 \\
\hline 1974.7126 & 1975 & + & - & - & - & - & - & 435 \\
\hline \multirow{2}{*}{\multicolumn{3}{|c|}{ Summary: }} & +4 & 6 & 4 & 5 & & \\
\hline & & & -8 & 6 & 8 & 7 & & \\
\hline
\end{tabular}

Amount of rain below average in $29 / 48$ months (60\%). 
$2000-$
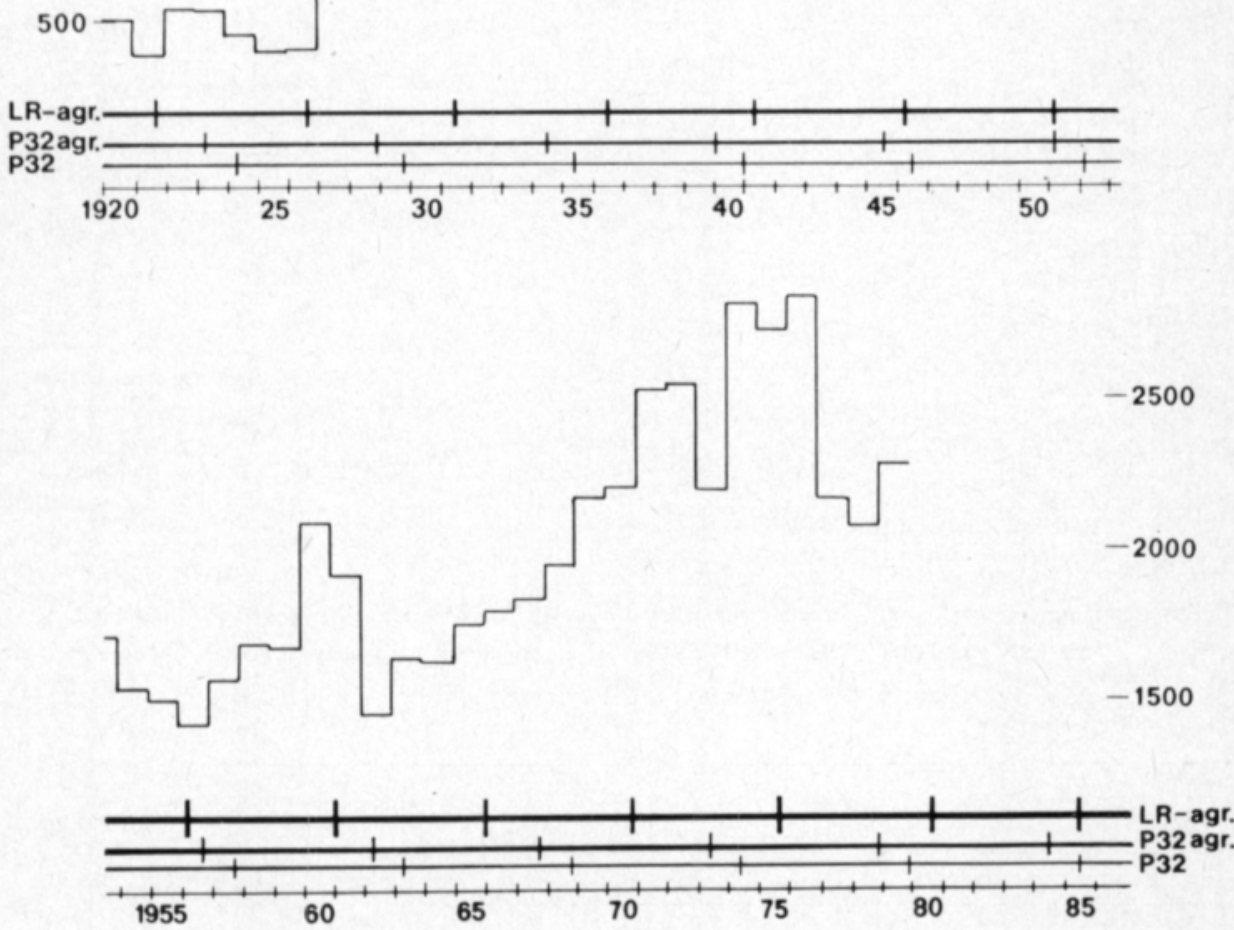

Fig. 5. Diagram of the yearly amount of crops of spring wheat in kilogrammes per hectare during the years $1920-1979$ in Finland. Below the diagram are shown the lunar scale LR-agr. (period 4.9035 years) and two planetary scales P32agr. and P32 (period 5.5613 years). 
Table 3. Planetary Scale P32agr. Monthly temperature in the growth season compared with average. Helsinki 1923-1978. Period: 5.561343 y. Start: 1961.25788 - below average, +- average, + above average.

$1931-1960$

\begin{tabular}{lcccccccc} 
average, C: & & 2.9 & 9.3 & 14.5 & 17.8 & 16.5 & 11.7 & 5.4 \\
\hline Scale & Year & (Apr.) & May & June & July & Aug. & (Sept.) & Year
\end{tabular}

1922.3284

1927.8898

1933.4516

1939.0125

1944.5738

1950.1351

1955.6965

1961.2578

1966.8192

1972.3805

1977.9419

$\begin{array}{ll}1923 & - \\ 1928 & +- \\ 1934 & + \\ 1940 & - \\ 1945 & + \\ 1951 & + \\ 1956 & - \\ 1962 & + \\ 1967 & + \\ 1973 & + \\ 1978 & -\end{array}$

$\begin{array}{ll}- & - \\ - & -\end{array}$

$+\quad+$

$-$

$-$

$-\quad 4.1$
$-\quad 4.6$

$+\quad+$

$+$

$+$

$-$

- -

$+$

$+$

7.2

- $\quad-$

$+$

$-$

- 3.6
- 3.6

$-\quad+$

$-$

$+$

$-$

5.6

$\begin{array}{ll}- & - \\ + & -\end{array}$

$-$

$+$

$+$

$+\quad-$

$-$

$-$

$-$

$\begin{array}{lll}- & - & - \\ - & - & +\end{array}$

$+$

\begin{tabular}{|c|c|c|c|c|}
\hline \multirow[t]{3}{*}{ Summary: } & + & 5 & 4 & 4 \\
\hline & - & 6 & 6 & 7 \\
\hline & +- & & 1 & \\
\hline
\end{tabular}

Monthly temperature below average in $27 / 44$ months $(61 \%)$.

Table 4. Planetary Scale P32agr. Amount of rain in the growth season compared with average. Helsinki 1923-1978. Period: 5.561343 y. Start: 1961.257 88. Scale in Table 3. - below average, +- average, + above average, $++>70 \mathrm{~mm} .,+++$ $>100 \mathrm{~mm}$.

\begin{tabular}{cccccccc}
\hline $\begin{array}{l}1931-1960 \\
\text { average, mm.: }\end{array}$ & 42 & 37 & 47 & 62 & 66 & 66 & 647 \\
\hline Year & (Apr.) & May & June & July & Aug. & (Sept.) & Year \\
\hline & & & & & & & \\
1923 & - & + & + & - & +++ & ++ & 798.6 \\
1928 & - & +++ & ++ & - & +++ & + & 783.4 \\
1934 & +- & - & - & + & - & + & 629.4 \\
1940 & - & - & + & - & - & +++ & 592.2 \\
1945 & + & - & + & ++ & ++ & - & 707 \\
1951 & + & - & + & - & - & - & 556.6 \\
1956 & + & - & - & +++ & +++ & - & 711.4 \\
1062 & + & + & + & - & ++ & +++ & 758 \\
1967 & - & + & - & - & +++ & - & 699 \\
1973 & + & - & - & - & - & +++ & 549 \\
1978 & - & - & - & ++ & +++ & +++ & 605 \\
\hline
\end{tabular}


Table 5. Scales and the near future.

\begin{tabular}{cccl}
\hline $\begin{array}{c}\text { Scale } \\
\text { LR-agr. }\end{array}$ & $\begin{array}{c}\text { Calendar } \\
\text { Year }\end{array}$ & $\begin{array}{c}\text { Scales } \\
\text { P32agr. }\end{array}$ & P32 \\
\hline \multirow{2}{*}{1979.6162} & 1980 & & \\
& 1984 & 1983.5032 & \\
1984.5197 & 1985 & & 1984.5003 \\
1989.4232 & 1990 & 1989.0645 & \\
& 1991 & & 1990.0617 \\
1994.3267 & 1995 & 1994.6259 & \\
& 1996 & & \\
19992303 & 2000 & & \\
& 2001 & 2000.1872 & \\
& 2002 & & \\
& & & \\
& & & \\
\end{tabular}

\section{Scales and the near future}

Table 5 shows the years in the near future in Finland when there can be expected a reduction in the crop of spring wheat because of drought (LR-agr.), or cool weather in the growth season and abundant rain in time of the harvest (P32agr. and P32).

\section{Discussion}

What is the reason for this ascertained lunar and planetary periodicity? The changing of gravitation according to the periodical changing of the positions of the planets is the evident reason for the meteorological changes even if BAUR (1951) has contested it. But the lunar gravitation in relation to the earth is changing in intervals other than planetary ones. Therefore it must be kept in mind that the changing may also be the result of simultaneous lunar and planetary influence.

As regards the area of influence there are some signs of it being relatively large.

For instance in the years 1965 and 1975 of the lunar scale, the amount of crop was also reduced in the Soviet Union (RYAN 1966, RAYMond 1976). And in 1970 the amount of wheat crop in Europe decreased $5 \%$ in relation to the amount in 1969. The reason for this reduction in all cases was the drought, in 1970 in Britain, Argentina and Australia (BELL 1971) as well. It seems that for countries lying more to the south than Finland the importance of the lunar periodicity could be greater than that of the planetary one. 
Anon. The statistics of the National Board of Agriculture in Finland, 1920-1978. Helsinki

BAur, F. 1951. Extended-Range Weather Forecasting. Compendium of Meteorology p. 814-833. Am. Met. Soc., Boston.

BELL, P. 1971. The Year Book 1971 p. 149. Grolier. London.

Снichasov, G. N. 1973. Experiment in the classification of spring seasons in the northern Kazakhstan. Tr. glav. geofiz. Obs. 299: 152-158. Refer. in Agrarmeteorol. Bibliographie, Offenbach a.M. 1977 p. 491.

EкмAN, E. 1783. Undersökning om Årsväxtens förhållande och i synnerhet Missvärt-Åren i Swerige från år 1523 till år 1781. Samling af rön och avhandlingar rörande Landbruket. IV: 123-182. Stockholm.

FeKeTE, L. \& Stepesi, K. 1974. A stastical analysis of the length of rainy periods and their quantity of precipitation. Acta Climatol. 13: 25-40.

Grotenfelt, K. 1919. Aikaisemmista katovuosista Suomessa. Juhlajulkaisu E. G. Palménin 70-vuotispäiväksi. Porvoo.

- 1934. Katovuodet. Iso Tietosanakirja VI: 328-329. Otava. Helsinki.

LAмв, H. H. 1972. Problems and Practice in Longer-Range Weather and Climate Forecasting. Weather Forecasting for Agriculture and Industry. A Symposium. Ed. J. A. Taylor. p. 34-43. David \& Charles. Newton Abbot.

MANnila, T. 1980. Lunar and planetary periodicity of temperature and rainfall in Helsinki 1902-77. Geophysica, In print.

Raymond, E. 1976. Encyclopedia Year Book 1976. p. 519. Grolier incorp. New York.

Ryan, W. L. 1966. Encyclopedia Year Book 1966. p. 453. Grolier incorp. New York.

WRIGHT, P. B. \& FlooD, C. R. 1973. Method of assessing long range forecasts. Weather 28, 5: $178-187$.

Ms received March 19, 1980.

\section{SELOSTUS}

\section{Katovuosien lunarinen ja planetarinen jaksollisuus Suomessa ja Ruotsissa}

Tauno Mannila

Myllytie 3 A 7, 00140 Helsinki 14

47:stä katovuodesta Suomessa vuosilta $1347-1929$ on $40 \%$ esiintynyt 4.9035 vuotta käsittävää lunarista jaksoa vastaavin väliajoin. Samankaltainen tulos saatiin Ruotsissa 15261772 olleen 77 katovuoden suhteen. - Kun katovuonna todetun neljän jättiplaneetan asemat tai niiden keskinäiset kulmaetäisyydet ovat uusiutuneet, on myös katovuosi saattanut uusiutua.

Kevätvehnän keskimääräinen hehtaarisato Suomessa 1920-1979 on vähentynyt edelliseen ja/tai seuraavaan vuoteen verrattuna lunarisen jakson, 4.9035 vuoden, väliajoin, kun tämä skaala LR - agr. on aloitettu kasvukaudesta, jolloin kuukautiset sademäärät ovat olleet keskimääräistä vähäisemmät. - Vielä suurempi kevätvehnän satomäärän vähentyminen ja esiintymistiheys 9 vuotta 10:stä on Suomessa todettavissa planetarisen skaalan P32agr.:n jaksolla, joka on 5.5613 vuotta. Skaala P32 agr. edustaa kasvukautta, jolloin ilman lämpötila on $61 \%$ ajasta keskimäärää alhaisempi ja sademäärä touko- ja heinäkuussa keskimääräistä vähäisempi kun taas elokuussa sademäärä ylittää keskimäärän. - Toinen meteorologinen skaala P32täydentää skaalaa P32agr. - Skaalojen avulla voidaan tehdä ennusteita. 